\title{
MAPPING TREND IMPLEMENTASI STRATEGI PROMOSI DESA WISATA KEMBANGARUM TURI SLEMAN YOGYAKARTA
}

\author{
Atun Yulianto \\ NIDN 0505077401 \\ Email:atun.aty@bsi.ac.id \\ Universitas Bina Sarana Informatika \\ Citra Unik Mayasari \\ NIDN 0511039201 \\ Email: citra.cyu@bsi.ac.id \\ Universitas Bina Sarana Informatika
}

\begin{abstract}
Kabupaten Sleman has many tourist attraction objects that can be used as tourist destinations for anyone. The attraction of this city includes the panorama of nature, history, museums, culture, ancient relics, culinary and tourist villages. The number of tourist villages in Sleman regency is in accordance with the data of the Sleman Regency Culture and Tourism Office (Fauzy \& Putra, 2015), as many as 38 tourist villages. The tourism village management base generally involves many parties, including by empowering local communities as local communities who play an active role in managing and developing tourism villages. However, according to (Damanik, 2013), "The weak point of the local community in managing tourism services is networking and promotion capabilities". The success of the tourism village manager in influencing the perception of visitors with their promotional tools can trigger the decision to visit. In this case, the right selection of promotional tools (promotional mix) is very important in addition to attracting tourists, as well as the progress of the tourism village itself. The number of tourist visits is a measure of the success of managers in developing the right promotional strategies. The constraints faced by the manager of the tourist village of Kembangarum Turi Sleman Yogyakarta are related to the weak network for promotion. A promotion has been carried out both conventionally and through internet media but not yet interactive, thus reducing the understanding of the wider community of the existence of the Kembangarum tourism village. The research method used is a qualitative descriptive method assisted with quantitative data tabulation. The results of the study with relevant data that is read indicate the trend of a shift in the implementation of promotional strategies with media that are conventional to modern with the help of information technology, especially the internet since the period 2015/2016. The conclusions of this study include: it is known that the most optimal use of conventional promotional media is by providing brochures, and word of mouth information. Whereas in the span of the last three years the promotion has focused more on online promotional media through social networks that have been owned by the tourism village manager of Kembangarum. This shift in promotion strategy proved to have an impact on increasing the number of tourist village visitors, especially in the period of 2016/2017 where this promotional strategy began to be implemented since the period of $2015 / 2016$.
\end{abstract}

Keywords: Promotion, Strategy,Trend Mapping,

PENDAHULUAN

Wilayah Kabupaten Sleman terkenal kaya akan keindahan alamnya. Dimana batas wilayahnya disebelah utara dengan Kabupaten Boyolali, sebelah timur berbatasan dengan Kabupaten Klaten Propinsi jawa tengah, sebelah barat berbatasan dengan Magelang Propinsi Jawa Tengah, Kabupaten Kulon Progo Propinsi D.I.Yogyakarta, dan sebelah selatan 
berbatasan dengan Kota Yogyakarta, Kabupaten Bantul dan Kabupaten Gunung Kidul, Propinsi D.I. Yogyakarta. Luas Wilayah Kabupaten Sleman adalah 57.482 Ha atau $574,82 \mathrm{Km}^{2}$ dan secara administratif terdiri 17 wilayah Kecamatan, 86 Desa, dan 1.212 Dusun (PEMKAB Sleman). Kabupaten Sleman hampir setengah dari luas wilayahnya merupakan tanah pertanian yang subur dengan didukung saluran irigasi yang baik sehingga sebagian masyarakatnya berprofesi sebagai petani.

Kabupaten Sleman memiliki banyak potensi objek wisata yang dapat dijadikan sebagai destinasi tujuan wisata. Potensi ini meliputi wisata alam, sejarah, museum, budaya, peninggalan purba kala, kuliner dan desa wisata.Wisata daerah kabupaten Sleman jumlahnya cukup banyak dan menarik dikunjungi oleh wisatawan baik dalam maupun luar negeri. Potensi lain yang menarik untuk dikunjungi wisatawan yaitu sejumlah desa wisata. Desa Wisata dalam PERMENBUDPAR No. PM.26/UM.001/MKP/2010 disebutkan sebagai suatu bentuk integrasi antara atraksi, akomodasi dan fasilitas pendukung yang disajikan dalam suatu struktur kehidupan masyarakat yang menyatu dengan tata cara dan tradisi yang berlaku.

Perkembangan jumlah pengunjung desa wisata di Kabupaten Sleman dari tahunketahun terus mengalami peningkatan. Data Dinas Pariwisata DIY tahun 2016 dalam buku Statistik Kepariwisataan Tahun 2015, sejak tahun 2011 sampai tahun 2015 menunjukkan peningkatan dari segi jumlah kunjungan.

Tabel 1. Jumlah Kunjungan Wisatawan Ke Desa Wisata Di Kabupaten Sleman Periode Tahun 2011 sampai dengan 2015

\begin{tabular}{|c|l|c|c|c|c|c|}
\hline \multirow{2}{*}{ No } & \multirow{2}{*}{ Wisatawan } & \multicolumn{5}{|c|}{ Tahun } \\
\cline { 3 - 7 } & & $\mathbf{2 0 1 1}$ & $\mathbf{2 0 1 2}$ & $\mathbf{2 0 1 3}$ & $\mathbf{2 0 1 4}$ & $\mathbf{2 0 1 5}$ \\
\hline 1 & Asing & 852 & 31.087 & 8.646 & 16.039 & 1.569 \\
\hline 2 & Nusantara & 101.568 & 106.194 & 149.124 & 202.473 & 254.363 \\
\hline & Jumlah & 102.420 & 137.281 & 157.770 & 218.512 & 255.932 \\
\hline
\end{tabular}

Sumber: (Dinas Pariwisata DIY, 2015) - Diolah

Jumlah desa wisata di kabupaten Sleman sesuai data Dinas Kebudayaan dan Pariwisata Kabupaten Sleman dalam (Fauzy \& Putra, 2015), tercatat sebanyak 38 desa wisata, dengan kemungkinan bertambah terus sampai saat ini. Desa wisata merupakan salah satu unsur penting dalam pembangunan sektor pariwisata yang menyajikan pelayanan dan fasilitas yang dapat dinikmati oleh wisatawan berbasis pemberdayaan masyarakat. Pemberdayaan masyarakat menurut Hadiwijoyo (2012) dalam (Ihtifazhuddin \& Abdurrahman dkk, 2016),merupakan proses perubahan struktur yang harus muncul dari masyarakat, dilakukan oleh masyarakat, dan hasilnya ditujukan untuk kesejahteraan masyarakat.

Dengan adanya desa wisata tentunya akan memberikan manfaat sosial bagi masyarakat khususnya keuntungan secara ekonomi maupun interaksi sosial. Laporan kajian ahli (Vorlaufer, 1996; Max, 2004; Rose, et.all,
2004; WTTC, 2006) dalam (Damanik, 2013), menyampaikan bahwa sumbangan secara ekonomi yang secara signifikan pada perkembangan ekonomi suatu negara atau daerah tampak dalam bentuk perluasan peluang kerja, peningkatan pendapatan (devisa), dan pemerataan pembangunan spasial. Sebuah desa wisata harus memiliki beberapa komponen yang berpotensi menjadi daya tarik pengembangan pariwisata sehingga dapat mendatangkan wisatawan dan tentunya menyerap tenaga kerja dari masyarakat setempat.

Keputusan berkunjung wisatawan ke desa wisata Kembangarum Turi Sleman memerlukan triger berupa promosi yang menarik sebagai penggerak untuk menciptakan tingkat kepercayaan calon pengunjung datang ke tempat tersebut. Namun demikian menurut (Damanik, 2013), "Titik lemah komunitas masyarakat lokal dalam mengelola usaha jasa pariwisata 
adalah jaringan (networking) dan kemampuan berpromosi". Dalam hal ini pemilihan kebutuhan alat-alat promosi (bauran promosi) yang tepat sangat penting bagi pengelola.

Keberhasilan pengelola desa wisata dalam mempengaruhi persepsi pengunjung dengan alat-alat promosinya dapat mencetuskan keputusan berkunjung. Keputusan berkunjung wisatawan merupakan keberhasilan pengelola dalam menyusun strategi promosi yang tepat. Kendala yang dihadapi pengelola desa wisata Kembangarum Turi Sleman Yogyakarta berkaitan dengan lemahnya jaringan untuk promosi. Promosi yang masih mengandalkan cara konvensional dan internet yang belum interaktif manjadi kendala dalam menyebarluaskan informasi tentang potensi desa wisata Kembangarum Turi Sleman ke masyarakat luas.

Berdasarkan latar belakang ini peneliti tertarik untuk membuat sebuah mapping trend strategi promosi desa wisata Kembangarum Turi Sleman untuk mengetahui alat promosi paling potensial melalui analisis kekuatan, kelemahan, peluang dan ancaman dari strategi promosi yang telah diterapkan. Dengan penelitian ini diharapkan ditemukan alternatif solusi atas kendala-kendala yang masih dihadapi pengelola dalam meningkatkan jumlah kunjungan wisatawan ke desa wisata Kembangarum Turi Sleman Yogyakarta.

\section{LITERATURE REVIEW Mapping Trend}

Menurut (Parkhurst \& Preskill, 2016), menjelaskan bahwa "A trend map is a visual depiction of relevant trends influencing the system around a given topic". Penjelasan ini dapat diartikan bahwa, Peta trend (Mapping Trend) adalah gambaran visual dari trend (kecenderungan) relevan yang mempengaruhi sistem di sekitar objek permasalahan yang sedang berkembang untuk keberlangsungan suatu usaha.

Mengembangkan peta trend dapat membantu bagi sebuah unit usaha/organisasi dalammempertajam pemahaman mereka tentang suatu masalah yang dihadapi melalui tehnik eksplorasi dari catatan historisyang dimiliki, mengidentifikasikan faktor-faktor internal dan eksternal yang mempengaruhi, serta dengan melacak pergeseran dalam norma-norma sosial budaya masyarakat/organisasi yang sedang berkembang saat ini.

\section{Desa Wisata}

Salah satu bentuk pembangunan ekonomi berbasis kerakyatan dalam bidang pariwisata adalah pengembangan desa wisata. Desa Wisata adalah suatu bentuk integrasi antara atraksi, akomodasi dan fasilitas pendukung yang disajikan dalam suatu struktur kehidupan masyarakat yang menyatu dengan tata cara dan tradisi yang berlaku (KEMENBUDPAR, 2010). Jadi masyarakat dapat menjadi komponen utama pembangunan pariwisata berbasis kemasyarakatan yang berperanan penting dalam menunjang pembangunan pariwisata daerah yang ditujukan untuk mengembangkan potensi lokal dengan bersumber dari alam, sosial budaya ataupun ekonomi masyarakat (Saktiawan, 2010).

Atas dasar landasan diatas pemerintah menyusun program untuk memberdayakan masyarakat melalui program nasional pemberdayaan masyarakat mandiri (PNPM) pariwisata melalui desa wisata. Pemberdayaan Masyarakat adalah upaya untuk meningkatkan kesadaran, kapasitas, akses, dan peran masyarakat, baik secara individu maupun kelompok, dalam memajukan kualitas hidup, kemandirian, dan kesejahteraan melalui kegiatan Kepariwisataan (Peraturan Pemerintah No 50 Tahun 2011). Unsur-unsur yang harus ada di desa wisata selain atraksi, akomodasi dan fasilitas penunjuang, dibutuhkan juga empat unsur pokok penawaran produk wisata sebagai suatu kesatuan totalitas produk, menurut Ariyanto dalam (Utama \& Mahadewi, 2012) yaitu:

1. Attractions (daya tarik). Tersedianya daya tarik wisata di daerah tujuan wisata berupa daya tarik alam, budaya masyarakat dan fasilitas penunjangnya. 


\section{Accesabillity}

(transportasi).

Tersedianya jalan dan transportasi untuk wisatawan domestik maupun manca negara dapat dengan mudah mencapai tujuan tempat wisata.

3. Amenities (fasilitas). Tersedianya fasilitas utama maupun pendukung pada sebuah destinasi wisata yang berupa akomodasi, restoran, penukaran valas, pusat oleh-oleh, dan fasilitas pendukung lainnya yang berhubungan dengan aktifitas wisatawan pada sebuah destinasi.

4. Ancillary (kelembagaan). Adanya lembaga pengelola perjalanan wisatawan sehingga kegiatan wisata dapat berlangsung. Hal ini dapat berupa pemandu wisata, biro perjalanan, pemesanan tiket, dan ketersediaan informasi tentang destinasi wisata.

\section{Strategi Promosi}

Strategi adalah rute yang dibutuhkan agar sampai pada tempat tujuan. Strategi merupakan cara untuk meningkatkan usaha dari satu tingkat yang lebih rendah ke tingkat selanjutnya dan menentukan arah, memberi motivasi, membimbing mulai dari awal sampai akhir (Grade, 2008). Menurut (Sumarsono, et.al, 2006), strategi pada dasarnya merupakan seni dan ilmu menggunakan dan mengembangkan kekuatan (ideologi, politik, sosial, ekonomi, dan hankam) untuk mencapai tujuan yang telah ditetapkan sebelumnya.

Promosi menurut Zimmere (2002) dalam (Rangkuti, 2009) adalah "segala macam bentuk komunikasi persuasi yang dirancang untuk menginformasikan ke pelanggan tentang produk atau jasa dan untuk mempengaruhi mereka agar membeli barang atau jasa tersebut yang mencakup publisitas, penjualan perorangan dan periklanan". Jadi promosi sifatnya adalah memberitahukan segala sesuatu tentang bentuk usaha kita mulai dari tempat usaha, memperkenalkan produk, pemberian diskon, fasilitas pelanggan agar terbujuk membeli melalui berbagai media atau alat promosi yang biasa disebut bauran promosi.
Bauran promosi yang umum digunakan oleh berbagai jenis perusahaan untuk mengkomunikasikan manfaat dari barang atau jasa yang akan dijual dilakukan dengan berbagai cara seperti memasang iklan, promosi penjualan dengan diskon/hadiah, penjualan perseorangan dan huubungan masyarakat. Menurut Angipora dalam (Huda, Hudori, Fahlevi, Badrussa'diyah, Mazaya, \&Sugiarti, 2017), bauran promosi adalah "kombinasi dari variable-variable periklanan, personal selling dan alat promosi lainnya, yang kesemuanya direncanakan untuk mencapai tujuan program penjualan". Jadi hal yang perlu diperhatikan dalam promosi adalah pemilihan bauran promosi yang terdiri atas : iklan, penjualan perorangan, promosi penjualan, hubungan masyarakat, informasi dari mulut ke mulut, dan surat pemberitahuan langsung kepada konsumen (Lupiyoadi \& Hamdani, 2009). Menurut (Dharmesta \& Handoko, 2003), tujuan utama promosi adalah untuk mendorong andanya permintaan.

Alat-alat pemasaran konvensional desa wisata yang dapat digunakan dalam promosi antara lain perikalanan di media masa, papan reklame, spanduk, baliho, brosure, selebaran, buku-buku kecil, dan lain-lain. Alat pemasaran lainnya adalah penawaran penjualan (personal selling), promosi penjualan dan pemasaran langsung. Sedangkan alat pemasaran modern yang sudah mulai digunakan pemasar dalam menyampaikan informasi produknya adalah website, e-mail, dan media sosial.

\section{METODE PENELITIAN}

Penelitian ini merupakan jenis penelitian yang bersifat diskriptif kualitatif menggunakan data-data riil untuk mengungkapkan fakta yang didukung analisis berdasarkan pada hasil penelitian dengan melihat sejauh mana implementasi strategi promosi sebuah desa wisata sehingga dapat disusun Mapping Trend yang paling efektif dalam mempengaruhi kunjungan wisatawan. Metode pengumpulan data merupakan suatu proses pengadaan data (primer) untuk keperluan penelitian (Utama 
\& Mahadewi, 2012). Dalam penelitian ini pengumpulan data dilakukan dengan cara observasi, interview, literature, dan survey.

Adapun langkah-langkah analisis data untuk menghasilkan pokok pembahasan penelitian yang diharapkan diantaranya sebagai berikut : (1) Mencantumkan apa yang menjadi Visi dan Misi pengelolaan desa wisata Kembangarum Turi Sleman Yogyakarta, (2) Mencantumkan tujuan desa wisata Kembangarum Turi Sleman di masa yang akan datang dalam meningkatkan jumlah kunjungan, (3) Mendapatkan data tentang jumlah dan target pasar wisatawan asing maupun domestik yang datang ke desa wisata Kembangarum Turi Sleman, (4) Memperoleh data tentang produk-produk wisata yang dikembangkan dan ditawarkan desa wisata Kembangarum Turi Sleman kepada pengunjung, (5) Mendapatkan data tentang alat strategi promosi baik konvensional maupun modern yang dilakukan baik secara offline dan online, (6) Mengetahui bentuk mapping trend implementasi strategi promosi desa wisata Kembangarum Turi Sleman

Analisis SWOT (strengths, weaknesses, opportunities, threats) digunakan untuk mengevaluasi hasil implementasi strategi promosi yang sudah berjalan mulai dari kekuatan, kelemahan, peluang, dan ancaman.

\section{HASIL PENELITIAN DAN PEMBAHASAN \\ Profile Desa Wisata Kembangarum}

Desa wisata Kembangarum merupakan desa wisata yang berbasis edukasi dan alam sebagai daya tarik wisata. Program-program yang di rancang dan di bangun banyak mengedepankan edukasi bagi anak-anak khususnya dan dewasa pada umumnya. Bapak Hery Kustriyatmo selaku Pimpinan Sanggar Pratista, berinisiatif menciptakan Dusun Kembangarum menjadi salah satu daerah tujuan wisata di Sleman, sebagai desa wisata pendidikan untuk dapat mendatangkan wisatawan.Desa wisata Kembangarum berdiri sejak 27 Juli 2005.Visi desa wisata Kembangarum yakni "Dengan Pengembangan Desa Wisata Kita Tingkatkan
Pembangunan Masyarakat". Guna mencapai visi tersebut, desa wisata Kembangarum mempunyai lima misi, meliputi: melestarikan dan memelihara kebersihan lingkungan hidup, melestarikan seni budaya tradisional yang ada ditengah-tengah masyarakat, memanfaatkan potensi wisata yang tersedia, memberikan pendidikan kepariwisataan pada masyarakat, dan meningkatkan kesejahteraan masyarakat.Desa wisata Kembangarum terletak di pedesaan kawasan lereng Merapi, tepatnya beralamat di Dusun Kembangarum, Donokerto, Turi, Sleman, Yogyakarta. Desa wisata Kembangarum ini berjarak $19 \mathrm{~km}$ dari kota Yogyakarta dengan 45 menit waktu tempuh.

\section{Strategi dan Media Promosi Desa Wisata Kembangarum}

Berdasarkan data hasil observasi yang dilakukan peneliti, Desa Wisata Kembangarum menerapkan beberapa jenis strategi promosi yang secara langsung tidak tertulis dalam rencana operasional, antara lain: strategi promosi dengan periklanan, strategi promosi penjualan, strategi promosi pemasaran langsung, strategi promosi melalui publisitas, strategi promosi penjualan pribadi dan strategi promosi media interaktif berbasis online. Dari hasil riset yang dilakukan peneliti dalam menggali informasi strategi promosi Desa Wisata Kembangarum Turi Sleman Yogyakarta tahun 2018, diperoleh tiga kategori strategi promosi yang digunakan, yaitu strategi promosi dengan media promosi offline (konvensional), online (modern) dan kerja sama.

Media promosi konvensional yang digunakan desa wisata Kembangarum sangat bervariasi sesuai kemampuan, tujuan dan kapasitas masing-masing yaitu : (1) Spanduk.Spanduk merupakan sebuah kain yang berukuran panjang dengan posisi dibentangkan dan memiliki tulisan atau gambar yang berisi informasi singkat tentang keunggulan suatu produk ataupun berisi peringatan umum (Winarta, 2017). Spanduk Desa Wisata Kembangarum dipasang dipinggir jalan pintu masuk Desa Wisata sebagai media informasi kepada masyarakat 
yang melintasi jalan sekitar lokasi dan pengunjung yang akan memasuki Desa Wisata tersebut. Spanduk yang dipasang sifatnya lokal dan tidak selalu dipasang diluar Desa Wisata terkait perijinan ke dinas terkait yang tidak mudah. (2) Baliho. Baliho memiliki peran seperti halnya spanduk, yaitu sebagai media yang berisi informasi untuk mempromosikan suatu produk dengan ukuran yang lebih besar dari pada spanduk. Dengan pertimbangan biaya perijinan dan design yang cukup mahal baliho Desa Wisata Kembangarum Turi Sleman dipasang secara insidental (lokal) didepan pintu masuk sebagai sebuah media informasi paket wisata, event dan fasilitas yang dapat diperoleh pengunjung selama berwisata. Kurangnya kemutahiran informasi yang tertulis dalam baliho menjadi alasan pengelola untuk tidak selalu memasang baliho. (3) Brosur (leaflet). Brosur adalah sebuah lembaran kertas ataupun terlipat yang berisi kata-kata informatif atas sebuah produk, layanan atau program dengan ditambahkan gambar terkait sebagai penarik perhatian yang ditujukan kepada masyarakat (Ees, 2006).Brosur disebarluaskan pengelola desa wisata Kembangarum dengan target masyarakat luas melalui instansi pemerintah, swasta, travel agent, sekolah, bank dan kepada masyarakat langsung. Brosur sudah dicetak berwarna secara berkala, walupun dari daya jangkau penyebaran sangat terbatas. Brosur masih menjadi salah satu alat promosi konvensional andalan bagi desa wisata Kembangarum. (4) Majalah. Majalah merupakan sebuah terbitan periodik (berkala) yang berisi tentang hasil liputan jurnalistik, maupun pandangan tentang topik-topik uptudate (aktual) yang layak untuk diketahui oleh para pembaca (Jaya, 2016). Publikasi promosi Desa Wisata Kembangarum secara insidental dilakukan melalui rubrik sebuah majalah salah satunya majalah Andong yang disajikan oleh maskapai penerbangan untuk dibaca penumpang dalam pesawat. Majalah Andong tidak setiap periodik memunculkan informasi tentang Desa Wisata Kembangarum, namun secara insidental rubrik ini dapat memberikan informasi kepada pembaca untuk mengenalkan potensi daya tarik wisata suatu daerah yang berbeda-beda. (5) Koran. Pada Kamus Besar Bahasa Indonesia (KBBI), koran diartikan sebagai lembaran-lembaran kertas yang berisi berita uptudate saat itu, yang terbagi dalam kolom-kolom dan diterbitkan dapat dalam hitungan hari, minggu atau bulanan secara periodik (Jaya, 2016). Pemberitaan tentang desa wisata Kembangarum oleh media cetak sifatnya tidak kontinyu tergantung dari ada tidaknya event atau kejadian luar biasa pada desa wisata tersebut, seperti kemenangan atas sebuah lomba desa wisata serta penghargaan lainnya yang dapat diangkat oleh wartawan sebagai sebuah berita menarik. (6)Word of Mout,adalah bentuk media promosi yang dilakukan dari mulut ke mulut berupa informasi rekomendasi atau referal konsumen, baik yang disampaikan secara lisan langsung (fisik) maupun melalui media online berupa text, gambar ataupun video (Sirait, 2009). Informasi dari mulut ke mulut yang dilakukan pengelola Desa Wisata Kembangarumdilakukan bersamaan pada saat konsumen menikmati produk wisata yang dibeli sebagai triger awal dari pemasar untuk membangun komunikasi dengan masyarakat melalui penciptaan komunitas masyarakat yang lebih luas. Cara ini dilakukan oleh pengelola karena tidak semua konsumen mempercayai bentuk promosi melalui iklan, majalah, brosure, spanduk dan sejenisnya, namum lebih mempercayai rekomendasi orang yang sudah pernah menggunakan produk yang sama. Promosi word of mouth dilakukan melalui balutan kegiatan wisata edukasi (pembelajaran) tentang produk wisata Kembangarum dengan memberikan pelayanan profesional pada saat konsumen menikmati paket wisata yang dibeli. Bentuk edukasi di Desa Wisata Kembangarum Turi Sleman dapat berupa cara membajak sawah, cara memelihara unggas, belajar gamelan, cara menganyam ketupat dan lain sebagainya.

Media Promosi Online Desa Wisata Kembangarum Turi Sleman dimulai sejak tahun 2015 dengan memanfaatkan media sosial sebagai salah satu media promosi 
kepada masyarakat luas. Alat promosi ini meliputi beberapa media online jejaring sosial yaitu : (1) Whatsapp. Whatsapp merupakan salah satu aplikasi massenger yang banyak digunakan untuk pengiriman data berupa pesan text, gambar, video film, suara, berkas dan map position dengan mudah, karena berbeda dengan sistem SMS (Short Message Service) sebelumnya yang hanya bisa mengirim pesan text (Kurniawan, 2016). Penggunaan media sosial whatsapp oleh pengelola Desa Wisata Kembangarum dalam melakukan promosi dan penetrasi pasar sudah dilakukan sejak tahun 2016 sampai dengan sekarang ini. (2) Instagram. Instagram adalah salah satu sosial media yang dapat berjalan diatas system operasi android dengan fungsi utamanya sebagai sarana menyebarkan informasi dan komunikasi dalam bentuk text, foto dan video kepada sesama pengguna instagram. Penggunaan instagram oleh pengelola Desa Wisata Kembangarum baru dimulai sejak tahun 2017. Informasi dalam akun instagram Desa Wisata Kembangarum menunjukkan bahwa selama penggunaan telah mengirimkan sebanyak 47 konten baik foto maupun video, memiliki 562 pengikut dan 579 akun lain yang diikuti. Namun disaat ini tentu jumlah kiriman maupun pengikut terus update dan bertambah sehingga informasi diatas sudah tidak berlaku untuk saat ini. (3) Twitter. Twiter merupakan jejaring sosial dan microblogging yang berbasis pesan pendek dimana seorang pengguna dapat memberikan informasi terkini tentang dirinya, bisnisnya maupun kegiatannya kepada sesama pengguna twitter yang mengikutinya (Elcom, 2010). Twitter digunakan pengelola Desa Wisata Kembangarum sebagai salah satu media promosi sejak akhir tahun 2017 yang lalu.Sesuai informasi umum yang ada pada gambar pagetwitter Desa Wisata Kembangarum menunjukkan bahwa admin telah mengirim 2.088 pesan, 970 pengikut dan mengikuti sebanyak 354 twitter lain dengan 4 informasi yang disukai pengguna lain. Tentunya pada saat ini semua informasi tersebut dapat berubah sesuai dengan data terbaru yang masuk. (4) Facebook. Facebook merupakan portal jejaring sosial yang dibuat oleh Mark Zuckerberg (Dipanegara, 2011), yang berfungsi sebagai sarana menyebarkan informasi dan komunikasi antar pengguna facebook baik dalam bentuk text, gambar maupun video. Sebagaimana sosial media yang lain, facebook Desa Wisata Kembangarum digunakan pengelola untuk mengenalkan, menginformasikan dan mengkomunikasikan kegiatan wisata yang ditawarkan kepada masyarakat luas. Terdapat 653 akun lain yang telah mengikuti facebook Desa Wisata Kembangarum dan sebanyak 654 pengunjung yang menyukai postingan yang dilakukan pengelola. (5) Website. Website merupakan keseluruhan halamanhalaman web yang terdapat dalam sebuah domain yang mengandung berbagai macam informasi (Yuhefizar, Mooduto, \& Hidayat, 2009). Desa Wisata Kembangarum Turi Sleman secara resmi belum memiliki website yang berdomain dot com atau berbayar lainnya, namun demikian banyak masyarakat yang memiliki kepedulian untuk membangunkan website berbasis blogspot dan wordpress sebagai sarana informasi dan promosi bagi kepentinngan Desa Wisata tersebut. Kekurangan dari pembangunan blog oleh orang lain ini adalah kurang updatenya informasi dengan terakhir posting di sebuah blog pada tanggal 2 Februari 2010. Ada banyak berita terpasang dibeberapa website resmi yang berisi tentang informasi berkaitan dengan Desa Wisata Kembangarum Turi Sleman seperti berita yang ada di yogyatrip.com dan liburanjogja.co.id.

Media promosi kerjasama dengan pihak eksternal merupakan bentuk upaya secara bersama-sama antar individu atau kelompok untuk mencapai suatu tujuan tertentu bersama-sama (Syarif \& Zainuddin, 2017). Kerjasama atas perjajian tertentu (kontrak) sudah dilakukan oleh pengelola Desa Wisata Kembangarum Turi Sleman dengan beberapa organisasi bisnis yang berhubungan dengan kepariwisataan, yaitu : (1) Offline Travel Agent. Offline travel agent yang sudah bekerja sama dengan Desa Wisata Kembangarum antara lain Mekar Wisata Tour \& Travel, Armada Tour \& 
Travel dan lain-lain. Kelebihan bekerja sama dengan travel agent konvensional ini diantaranya lebih dipercaya konsumen, segmentasi pasar terpetakan dengan jelas. Namun memiliki kekurangan yaitu jaringan konsumen yang tidak luas karena tidak menjual banyak jenis tiket. (2) Online Travel Agent (OTA). Online travel agent. Onlinetravel agent melakukan kegiatan transaksinya melalui layanan digital dunia maya, mulai dari pencarian informasi, pemesanan sampai pembayaran transaksinya dilakukan secara online (Traveloka, 2015). Beberapa online travel agent yang sudah ada di dunia saat ini antara lain : Booking.com, TripAdvisor.com, Hotels.com, Expedia.com, Agoda.com, Traveloka.com dan lain-lain. Desa Wisata Kembangarum secara langsung belum melakukan kerja sama dengan online travel agent (OTA). Namun demikian secara tidak langsung kerjasama dengan OTA dilakukan melalui pihak ke-tiga yaitu travel agent konvensional yang sudah bekerja sama dengan Desa Wisata Kembangarum. (3) Hubungan Masyarakat. Hubungan masayarakat (humas) dilakukan Desa Wisata Kembangarum dengan usaha interaktif dan komunikatif yang sopan antara perusahaan dengan masyarakat sekelilingnya, sehingga berdampak mendasar pada citra baik dan keberhasilan usaha Desa Wisata Kembangarum. Hubungan masyarakat sendiri difungsikan sebagai komunikator baik melalui lisan maupun tulisan (media cetak) yang baik dan sopan, membina relasi dengan mayarakat sekitar dan internal karyawan.
Upaya humas ini menjadi pendukung kegiatan pemasaran yaitu promosi word of mouth dan membangun citra yang positif bagi Desa Wisata Kembangarum Turi Sleman. Perlu diketahui bahwa fungsi humas di Desa Wisata Kembangarum masih perlu diperluas ke luar khususnya kepada instansi pemerintah dan swasta, sehingga secara tidak langsung dapat meluaskan jaringan promosi bagi desa wisata.

\section{Mapping Trend Strategi Promosi Desa Wisata Kembangarum}

Menurut (Parkhurst \& Preskill, 2016), menjelaskan bahwa "A trend map is a visual depiction of relevant trends influencing the system around a given topic”. Penjelasan ini dapat diartikan bahwa, Peta trend (Mapping Trend) adalah gambaran visual dari trend (kecenderungan) relevan yang mempengaruhi sistem di sekitar objek permasalahan yang sedang berkembang untuk keberlangsungan suatu usaha.

Pengembangan peta trend implemantasi strategi promosi dapat membantu Desa Wisata Kembangarum dalam memperdalam pemahaman mereka tentang upaya promosi mereka melalui eksplorasi histori kegiatan terkait, mengidentifikasi faktor-faktor eksternal yang mempengaruhi upaya promosi, dan melacak pergeseran kecenderungan masyarakat secara sosial dan budaya. Mapping trend implementsai strategi promosi Desa Wisata Kembangarum dapat digambarkan dalam bentuk tabel dibawah ini.

Tabel 2. Mapping Trend Implementasi Startegi Promosi Desa Wisata

Kembangarum Turi Sleman Yogyakarta

\begin{tabular}{|c|c|c|}
\hline \multicolumn{3}{|c|}{ DESA WISATA KEMBANGARUM TURI SLEMAN } \\
\hline \multicolumn{3}{|c|}{ Tujuan Desa Wisata } \\
\hline \multicolumn{3}{|c|}{ 1. Mengembangkan desa wisata yang edukatif } \\
\hline \multicolumn{3}{|c|}{ 2.Mengenalkan potensi desa wisata ke luar daerah } \\
\hline \multicolumn{3}{|c|}{ 3.Kesejahteraan masyarakat sekitar } \\
\hline \multicolumn{3}{|c|}{ 4.Memperoleh keuntungan dari pelayanan wisatawan } \\
\hline Visi Lama & & Misi \\
\hline $\begin{array}{c}\text { Dengan Pengembangan Desa Wisata Kita } \\
\text { Tingkatkan Pembangunan Masyarakat }\end{array}$ & 1 & $\begin{array}{l}\text { Melestarikan dan memelihara kebersihan lingkungan } \\
\text { hidup }\end{array}$ \\
\hline Visi Baru & 2 & $\begin{array}{l}\text { Melestarikan seni budaya tradisional yang ada } \\
\text { ditengah-tengah masyarakat }\end{array}$ \\
\hline \multirow[b]{2}{*}{ "Datang senang pulang tambah pintar" } & 3 & Memanfaatkan potensi wisata yang tersedia \\
\hline & 4 & $\begin{array}{l}\text { Memberikan pendidikan kepariwisataan pada } \\
\text { masyarakat }\end{array}$ \\
\hline
\end{tabular}




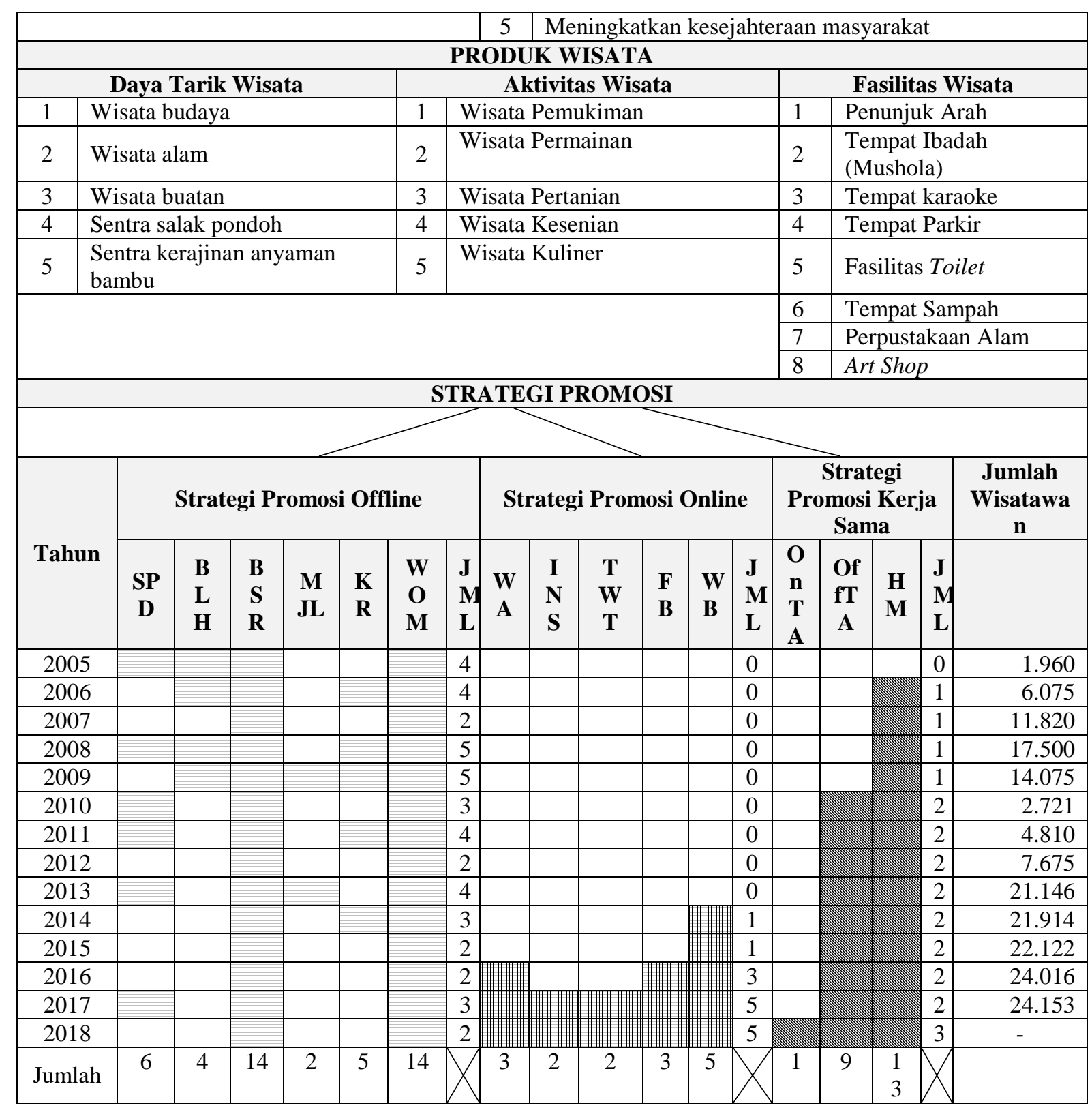

Keterangan :

- SPD : spanduk, BLH: baliho, BSR $\quad$ : brosur, MJL: majalah, KR $\quad$ : koran, JML: jumlah, WOM: word of mouth, WA : whatsapp, FB : facebook, WB: website, OnTA: online travel agent, OffTA: offline travel agent, $\mathrm{HM}$ : hubungan masyarakat

Dengan melihat tabel 2, implementasi strategi promosi Desa Wisata Kembangarum dalam kurun waktu 14 tahun terakhir, dapat disimpulkan bahwa media promosi yang paling banyak dioptimalkan adalah media brosur dan informasi dari mulut ke mulut (word of mouth). Sedangkan hubungan masyarakat digunakan sebagai bagian dari kegiatan pendekatan kepada warga sekitar dengan memberikan kesadaran untuk dapat aktif ikut serta berpartisipasi membangun dan mendukung pengembangan Desa Wisata Kembangarum.

Kecenderung trend implementasi strategi promosi dalam 3 tahun terakhir menunjukkan adanya pergeseran alat promosi dari media promosi offline yang konvensional ke media online yang lebih interaktif dan cepat dalam mengupdate informasi terbaru dari Desa Wisata Kembangarum Turi Sleman Yogyakarta. Trend implementasi strategi promosi yang diterapkan Desa Wisata 
Kembangarum merupakan dampak dari fenomena mudahnya masyarakat dalam mengakses internet dan banyaknya smartpone yang telah memiliki fasilitas software jejaring sosial. Banyaknya masyarakat yang mengakses media online melalui smartphone mengubah pandangan pengelola Desa Wisata untuk turut aktif di dunia maya khususnya jejaring sosial dalam bentuk penerapan strategi promosi online.

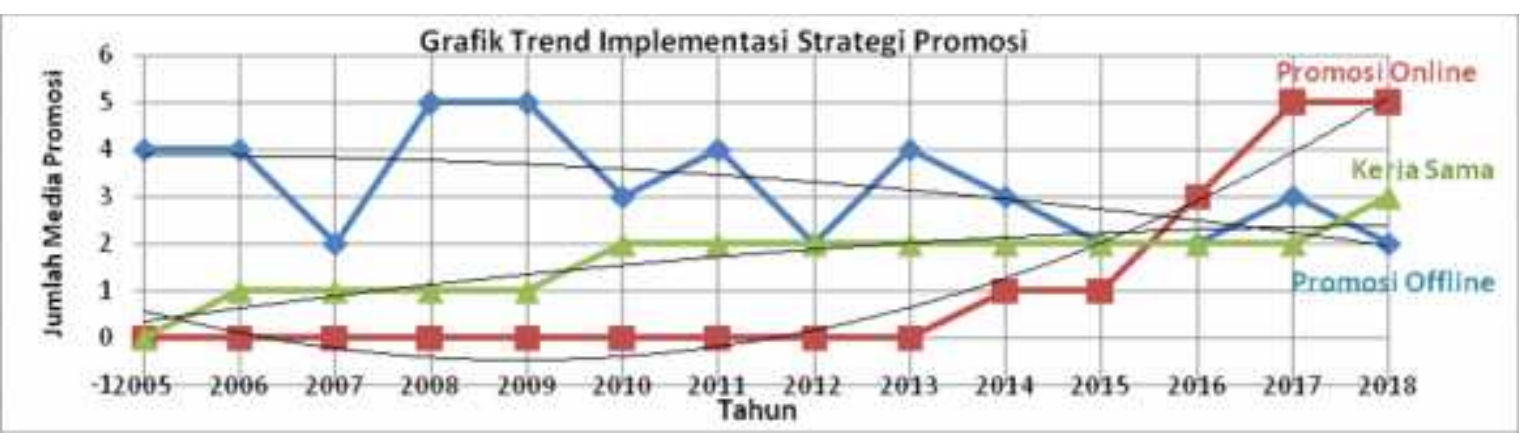

Gambar 1. Grafik Trend Implementasi Strategi Promosi Desa Wisata Kembangarum

Kecenderungan pertumbuhan implementasi strategi promosi online dan bentuk kerja sama Desa Wisata Kembangarum terindikasi dari gambar grafik1. menunjukkan pola pergerakan naik sejak tahun 2016.Perlu diketahui bahwa sampai saat ini dengan pola promosi online pengelola telah membangun beberapa account media sosial, sehingga orientasi promosi dan informasi sudah banyak dilakukan secara online. Account yang dimiliki antara lain whatsapp, twitter, facebook, dan instagram.
Dimedia promosi lain menunjukkan adanya penurunan penggunaan, khususnya pada media promosi konvensional (offline) sejak tahun 2014. Dari informasi pengelola menyebutkan bahwa media promosi offline dikurangi penggunaannya karena lebih banyak memakan anggaran biaya daripada online. Selain hal tersebut penyebaran informasi cenderung lebih lambat dan terbatas. Hasil dari perubahan strategi promosi yang diterapakan Desa Wisata Kembangarum diantaranya berdampak pada peningkatan jumlah kunjungan.

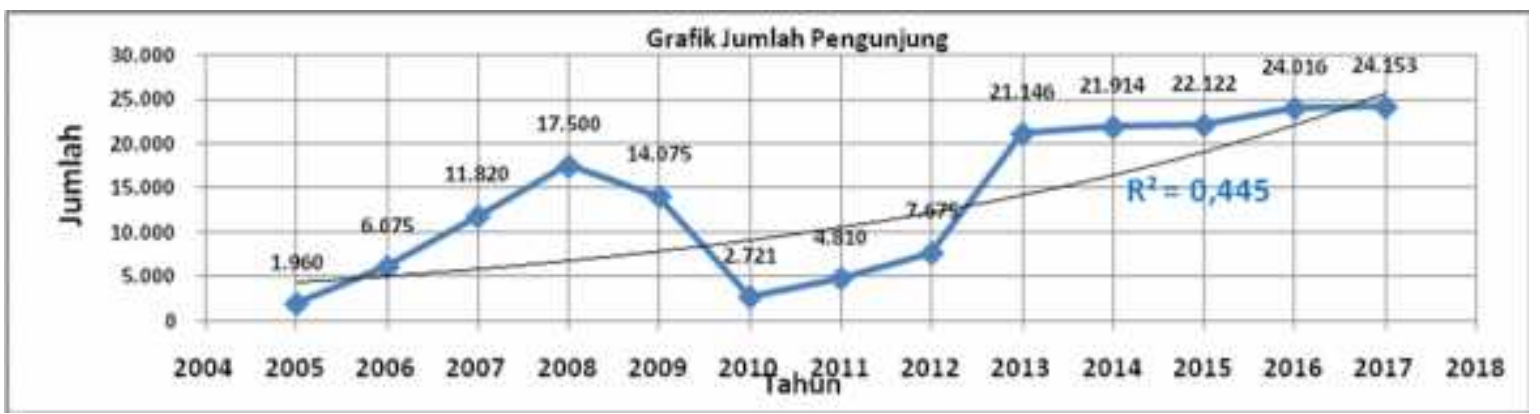

Gambar 2. Grafik Jumlah Pengunjung

Dengan implementasi strategi promosi yang ditetapkan Desa Wisata Kembangarum, pertumbuhan jumlah tamu yang menggunakan produk wisata Desa Kembangarum terus mengalami peningkatan. Peningkatan tajam terjadi pada tahun 2013/2014 dan terus berlanjut seiring dengan perubahan bentuk media promosi yang dikembangkan oleh pengelola desa wisata dengan menyesuaikan trend penggunaan media online oleh masyarakat Indonesia. Pada tahun 2015/2016 desa wisata mulai mengubah strategi promosiya dengan lebih fokus pada strategi promosi dengan media online, sebagai akibatnya kenaikan kunjungan yang cukup signifikan terjadi sejak tahun tersebut. 
Dilain kesempatan jumlah kunjungan wisatawan sempat mengalami penurunan tajam yaitu ditahun 2010. Hal tersebut sebagai dampak dari bencana alam yang dilanda kota Yogyakarta dan sekitarnya yaitu meletusannya gunung Merapi yang berada dekat dengan desa wisata. Koefisien

\section{SWOT Analisis Implementasi Strategi Promosi Desa Wisata Kembangarum}

Analisis SWOT (strengths, weaknesses, opportunities, threats) digunakan peneliti untuk mengetahui hasil implementasi strategi promosi yang sudah berjalan mulai dari kekuatan, kelemahan, peluang, dan ancaman dalam mengenalkan dan membujuk wisatawan berkunjung ke desa wisata Kembangarum Turi Sleman.

1. Kekuatan (strenghts), meliputi : (a) pengelola telah memiliki sejumlah account media sosial yang sedang trending untuk media promosi dan informasi online; (b) memiliki spanduk yang terpasang sepanjang tahun di sekitar desa wisata untuk memudahkan calon pengunjung mengenali lokasi; (c) brosur telah dicetak berwarna dan sangat menarik; (d) responsif dalam pelayanan tamu; (e) mengandalkan bentuk promosi pergaulan (word of mouth) yang tepat sasaran secara edukatif bersamaan dengan tamu saat mendapatkan pelayanan wisata; (f) memiliki dan mengikuti group-group komunitas whatsapp untuk media informasi dan promosi; (g) sudah banyak bekerjasama dengan travel agent konvensional (offline)

2. Kekurangan (weaknesses), meliputi : (a) kekurangan personil SDM untuk pemasaran (marketing); (b) update informasi melalui jejaring sosial tidak terjadwal dan belum memiliki accountyoutube untuk sarana promosi dalam bentuk video; (c) belum memiliki website resmi; (d) peran humas ke lingkungan eksternal belum maksimal; (e) spanduk dan baliho terpasang lokal disekitar desa wisata; (f) tidak setiap waktu informasi tentang desa wisata determinasi menunjukkan $\mathrm{R}^{2}=0,4455$ artinya pemilihan variabel jumlah dan tahun kunjungan dalam (cross section data) menjelaskan variasi kinerja data sebesar 40 persen, sisanya 60 persen ditentukan oleh variabel-variabel lain di luar model.

ditulis wartawan pada subuah media cetak (majalah/koran); (g) belum banyak bekerjasama dengan travel agent online

3. Peluang (opportunities), meliputi : (a) desa wisata sudah terkenal dengan beberapa penghargaan yang diperoleh; (b) masyarakat sudah banyak menggunakan tehnologi internet melalui jejaring sosial untuk update status tentang suatu objek wisata; (c) diminati banyak segmen khususnya sekolah dan instansi baik dalam maupun luar kota; (d) pelayanan yang dinikmati tamu sama dengan informasi promosi dari brosur yang diterimanya; (e) Pengelola Desa Wisata Kembangarum sudah mempelajari tanda-tanda alam khususnya kemungkinan gunung Merapi kembai meletus; (f) banyak pengunjung bloger dan youtuber mengangkat pesona keindahan desa wisata dengan mengupload text, gambar dan video melalui internet; $(\mathrm{g})$ banyak bermunculan travel agent online (OTA) yang memberikan peluang kerjasama (affiliasi) kepada pihak-pihak yang membutuhkan.

4. Ancaman (threaths), meliputi : (a) banyaknya resto menarik berbentuk joglo disekitar lokasi desa wisata; (b) gejolak ekonomi dunia; (c) isu bencana alam yang dimungkinkan terjadi seperti gempa bumi dan letusan gunung merapi; (d) banyaknya pilihan tempat-tempat wisata yang ada di Jogjakarta; (e) persaingan dengan desa wisata sejenis di dalam dan luar daerah; (f) banyak instansi pemerintah mengefisienkan kegiatan diluar instansi karena dibatasi oleh peraturan.

Dari data-data yang berupa kekuatan, kelemahan, peluang dan ancaman tersebut dapat di-matching (mempertemukan) point- 
point setiap elemen SWOT. Prinsip mempertemukan data SWOT ini dapat membentuk sebuah pernyataan yang memiliki nilai (makna) sebagai salah satu penentu kebijakan dalam pengembangan strategi promosi yang lebih mendekati kebutuhan pasar saat ini. Bentuk matching disajikan dalam tabel matrik SWOT dibawah ini.

Tabel 3. Matrik SWOT

\begin{tabular}{|c|c|c|c|}
\hline \multirow{2}{*}{\multicolumn{2}{|c|}{$\begin{array}{l}\quad \begin{array}{l}\text { Kekuatan } \\
\text { Internal }\end{array} \\
\text { Kekuatan } \\
\text { Ekternal }\end{array}$}} & \multicolumn{2}{|c|}{ Internal } \\
\hline & & Kekuatan (S) & Kelemahan (W) \\
\hline \multirow[t]{3}{*}{ Eksternal } & Peluang (O) & $\begin{array}{l}\text { 1. Memanfaatkan kebiasaan } \\
\text { masyarakat berinternet dan } \\
\text { jejaring sosial sebagai media } \\
\text { promosi dan informasi melalui } \\
\text { account medsos pengelola } \\
\text { (like, upload, shared) } \\
\text { 2. Memanfaatkan minat } \\
\text { masyarakat dalam dan luar } \\
\text { kota berekreasi ke desa wisata } \\
\text { melalui jaringan travel agent } \\
\text { lokal maupun nasional yang } \\
\text { sudah terjalin dengan baik } \\
\text { Memanfaatkan tamu } \\
\text { komunitas bloger yang } \\
\text { berkunjung untuk mengangkat } \\
\text { pesona desa wisata dari } \\
\text { pelayanan yang diberikan } \\
\text { melalui internet. } \\
\text { Memanfaatkan kepercayaan } \\
\text { pengunjung menikmati } \\
\text { realitas pelayanan yang sama } \\
\text { dengan penawaran melalui } \\
\text { informasi promosi dari brosur } \\
\text { yang menarik }\end{array}$ & 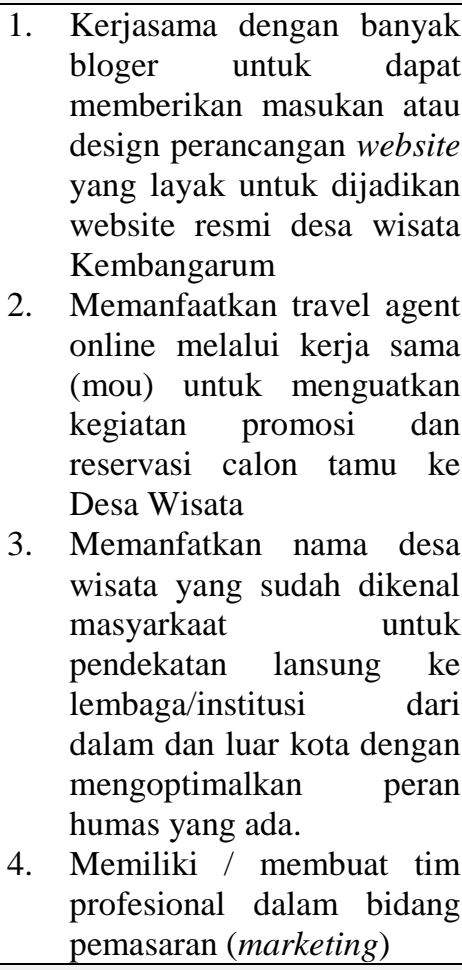 \\
\hline & & S-T & $\mathbf{W}-\mathbf{T}$ \\
\hline & $\begin{array}{l}\text { Ancaman } \\
(T)\end{array}$ & $\begin{array}{l}\text { 1. } \begin{array}{l}\text { Mempertahankan } \\
\text { disekitar desa } \\
\text { mengalihkan untuk } \\
\text { masyarakat yang akan } \\
\text { banyaknya resto disekitar desa }\end{array} \\
\text { wisata } \\
\text { 2. } \begin{array}{l}\text { Menggunakan group-group } \\
\text { media sosial untuk menangkal }\end{array} \\
\text { segala isu negatif tentang } \\
\text { keamanan desa wisata dari } \\
\text { kemungkinan dampak letusan } \\
\text { gunung Merapi } \\
\text { Memberikan pelayanan yang } \\
\text { terbaik/prima } \\
\text { memenangkan persaingan } \\
\text { dengan objek wisata lain yang } \\
\text { sejenis } \\
\text { Memanfaatkan kerjasa dengan } \\
\text { travel agent untuk efiseiensi }\end{array}$ & 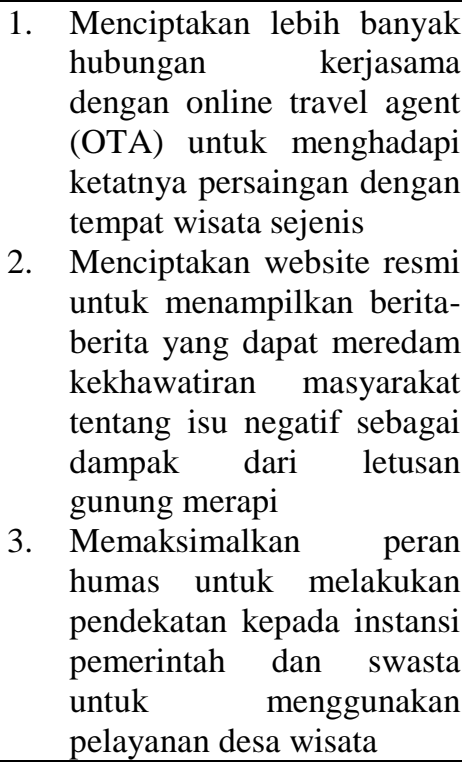 \\
\hline
\end{tabular}




\begin{tabular}{|l|l|l|l|}
\hline \multirow{2}{*}{} & $\begin{array}{l}\text { pengeluaran pemasaran dalam } \\
\text { menghadapi gejolak ekonomi }\end{array}$ & 4. & $\begin{array}{l}\text { Memberikan pelayanan } \\
\text { prima dengan } \\
\text { menyuguhkan service dan } \\
\text { produk yang inovatif agar } \\
\end{array}$ \\
& $\begin{array}{l}\text { bisa bersaing dengan } \\
\text { kompetitor }\end{array}$ \\
\hline
\end{tabular}

\section{KESIMPULAN DAN REKOMENDASI Kesimpulan}

Dengan pembahasan tentang pergerakan (mapping) trend implementasi setrategi promosi yang diterapkan oleh Desa Wisata Kembangarum Turi Sleman ini, maka dapat disimpulkan perubahan-perubahan yang terjadi dalam proses promosinya sebagai berikut :

1. Kemajuan tehnologi informasi berdampak pada perilaku masyarakat dalam menjalankan aktifitas kesehariannya. Internet menjadi salah satu faktor penting untuk memenuhi kebutuhan informasi bagi masyarakat. Implementasi strategi promosi Desa Wisata Kembangarum menunjukkan adanya perubahan dan penyesuaian dari bentuk media promosi yang digunakan sebagai akibat dari pergeseran kecenderungan masyarakat secara sosial dan budaya. Kecenderungan masyarakat ini terbaca oleh pengelola Desa Wisata Kembangarum, sehingga sejak 3 tahun terakhir mulai mengubah bentuk strategi promosi dengan media offlinenya ke strategi promosi dengan media online. Berdasarkan data hasil penelitian, penggunaan strategi momosi dengan media konvensional dioptimalkan pada penyediaan brosur dan informasi dari mulut ke mulut. Sedangkan dalam rentang waktu tiga tahun terakhir peningkatan promosi lebih memfokuskan pada media promosi online melalui jejarang sosial yang sudah dimiliki pengelola desa wisata Kembangarum. Pergeseran strategi promosi ini terbukti berdampak pada peningkatan jumlah pengunjung desa wisata khususnya pada periode tahun 2016 dan 2017, dimana strategi promosi ini mulai diterapkan sejak satu tahun sebelumnya.
2. Strategi promosi yang diterapkan pengelola Desa Wisata Kembangarum mulai bergeser dari konvensional ke pemanfaatan tehnologi informasi sejak akhir tahun 2015. Hal ini tidak lepas dari pengaruh beberapa faktor baik internal maupun eksternal. Hasil analisis SWOT berdasarkan skala prioritas analisis peneliti menunjukkan bahwa, kekuatan strategi promosi paling utama desa wisata Kembangarum saat ini adalah aktifnya pengelola dalam mengikuti group-group whatsapp dan media sosial yang sedang banyak digunakan masyarakat. Sementara kekurangan dari strategi promosi desa wisata Kembangarum adalah belum adanya website resmi dan kerjasama intensif dengan travel agent online yang dapat memperluas informasi promosi desa wisata. Sedangkan peluang yang dimiliki desa wisata Kembangarum saat ini adalah semakin familiernya masyarakat menggunakan internet dan munculnya banyak online travel agent. Ancaman-ancaman yang muncul dari strategi promosi desa wisata Kembangarum saat ini adalah bervariasinya jenis tempat wisata di Daerah Istimewa Yogyakarta sehingga banyak pilihan bagi masyarakat dan objek desa wisata sejenis khususnya yang berada di kabupaten Sleman.

\section{Rekomendasi}

Seiring dengan perkembangan tehnologi dan informasi saat ini, masih banyak strategi promosi yang dapat dikembangkan menyesuaikan dengan keadaan jaman yang ada, khususnya bagi pengelola Desa Wisata Kembangarum Turi Sleman, antara lain :

1. Menciptakan kerjasama yang saling melengkapi dan menguntungkan tidak hanya dengan pengelola travel agent 
konvensioanl (offline), namun dapat ditambah dengan pengelola jasa travel agent online, seperti booking.com, agoda.com, traveloka.com, trivago.com, airbnb.com dan sebagainya.

2. Bekerjasama dengan website programmer untuk membangun website resmi desa wisata Kembangarum dan tentunya dibarengi dengan hosting yang dapat mengonlinekan web tersebut.

3. Menempatkan personil khusus untuk aktif dan update informasi terjadwal melalui sosial media yang dimiliki desa wisata.

4. Menambahkan account sharing video melalui website youtube untuk upload video tentang desa wisata, sehingga dapat diakses oleh banyak masyarakat penguna youtube.

5. Meningkatkan peran humas dalam melakukan penetrasi pasar khususnya pada instansi pemerintah dan swasta baik didalam maupun luar kota.

\section{REFERENSI}

Damanik, J. (2013). Pariwisata Indonesia : Peluang Dan Tantangan. Yogyakarta: Pustaka Pelajar.

Dharmesta, B. S., \& Handoko, H. (2003). Manajemen Pemasaran : Analisis Perilaku Konsumen. Yogyakarta: BPFE.

Dinas Pariwisata DIY. (2015). Statistik Kepariwisataan 2015 (Jogja Istimewa). Yogyakarta: Dinas Pariwisata DIY.

Dipanegara, A. (2011). Facebook Hacker. Jakarta: Jal Publishing.

Ees. (2006). Kekuatan Garis Dan Warna Corel Draw 12 For Designer. Jakarta: PT. Elex Media Komputindo.

Elcom. (2010). Seri Belajar Kilat Twitter. Yogyakarta: CV Andi Offset.

Fauzy, A., \& Putra, A. S. (2015). Pemetaan Lokasi Potensi Desa Wisata Di kabupaten Sleman Tahun 2015. Jurnal Inovasi Dan Kewirausahaan FMIPA UII, 124-129.

Grade, R. (2008). 5 Strategi Ampuh Berbisnis. Yogyakarta: B-First.
Huda, N., Hudori, K., Fahlevi, R., Badrussa'diyah, Mazaya, D., \& Sugiarti, D. (2017). Pemasaran Syariah : Teori Dan Aplikasi. Depok: Kencana.

Ihtifazhuddin, W., \& Abdurrahman dkk. (2016). Perencanaan Pengembangan Desa Wisata Puspo Ardi, Talunombo, Sidomulyo Pengasih Kulon Progo DIY. Yogyakarta: Fak. Ekonomi Universitas Sarjanawiyata.

Jaya, B. K. (2016). Kuliah Jurusan Apa? BROADCASTING. Jakarta: PT. Gramedia Pustaka Utama.

KEMENBUDPAR. (2010). Program Nasional Pemberdayaan Masyarakat (PNPM) Mandiri Pariwisata Melalui Desa Wisata. Retrieved Februari 10, 2018, from http://www.kemenpar.go.id:

http://www.kemenpar.go.id/userfiles/fil e/1_\%20PERMEN\%20PNPM\%20

Kurniawan, D. (2016). Membangun Aplikasi Elektronika dengan Raspberry Pi 2 dan Whatsapp. Jakarta: PT. Elex Media Komputindo.

Lupiyoadi, R., \& Hamdani, A. (2009). Manajemen Pemasaran Jasa. Jakarta: Salemba Empat.

Parkhurst, M., \& Preskill, H. (2016). Guide to Trend Mapping. Retrieved 7 17, 2018, from fsg.org: https://www.fsg.org/tools-andresources/guide-trend-mapping

PEMKAB Sleman. (2018). http://www.slemankab.go.id/profilkabupaten-sleman/geografi/letak-danluas-wilayah. Retrieved Februari 10, 2018, from http://www.slemankab.go.id

Peraturan Pemerintah No 50 Tahun 2011. (2018). Retrieved Februari 10, 2018, from

http://www.bphn.go.id/data/documents/ 11pp050.pdf

Rangkuti, F. (2009). Strategi Promosi Yang Efektif Dan Analisis Kasus Integrated Marketing Communication. Jakarta: Gramedia Pustaka Utama. 
Saktiawan, F. (2010). Masyarakat Dalam Pengembangan Desa Wisata. Retrieved 2018 , from https://buletinbetungkerihun.wordpress. com/2010/11/12/pentingnyamembangun-partisipasi-masyarakatdalam-pengembangan-desa-wisata/

Sirait, C. B. (2009). Kiat cerdas berkampanye di depan publik. Jakarta: PT. Gramedia Pustaka Utama.

Sopian. (2016). Public Relations Writing: Konsep, Teori, Praktik. Jakarta: PT. Grasindo.

Sumarsono, et.al. (2006). Pendidikan Kewarganegaraan. Jakarta: Gramedia Pustaka Utama.

Syarif, A., \& Zainuddin, M. (2017). Inti Sari Sosiologi Pertanian. Makasar: CV. Inti Mediatama.
Traveloka. (2015, Oktober 4). Berita Satu. Retrieved Juli 24, 2018, from http://www.beritasatu.com/foodtravel/311491-\%09online-travel-agentsemakin-jadi-andalan-perjalanan-tanahair.html

Utama, I., \& Mahadewi, N. (2012). Metode Penelitian Pariwisata \& Perhotelan. Yogyakarta: CV. Andi Offset.

Winarta, B. T. (2017). 500 Ways To Multiply Your People 'S Productivity. Jakarta: PT. Gramedia.

Yuhefizar, Mooduto, H., \& Hidayat, R. (2009). Cara Mudah Membangun Website Interaktif

Menggunakan Content Management System Joomla. Jakarta: PT Elex Media Komputindo 